\title{
Financial Regulatory Harmonization and the Globalization of Finance
}

\section{Cally Jordan and Giovanni Majnoni**}

\begin{abstract}
In the globalizing economy, national policymakers are often forced to accept the challenge of financial integration. Faced with the potentially destabilizing effects of international financial markets, they have to strengthen financial regulation, importing international best practices and aligning domestic with foreign regulation to avoid destabilizing phenomena of regulatory arbitrage. This paper explores the main features of the ongoing process of worldwide financial regulatory convergence and the role played by the global dissemination of financial standards and codes. It analyzes the reasons behind the generalized acceptance of international best practices and the limits of the standards and codes approach to financial regulatory harmonization.
\end{abstract}

JEL classification numbers: G21, G28

Keywords: financial regulation, international financial system

World Bank Policy Research Working Paper 2919, October 2002

The Policy Research Working Paper Series disseminates the findings of work in progress to encourage the exchange of ideas about development issues. An objective of the series is to get the findings out quickly, even if the presentations are less than fully polished. The papers carry the names of the authors and should be cited accordingly. The findings, interpretations, and conclusions expressed in this paper are entirely those of the authors. They do not necessarily represent the view of the World Bank, its Executive Directors, or the countries they represent. Policy Research Working Papers are available online at http://econ.worldbank.org.

\footnotetext{
** We are grateful to Paola Bongini, Jim Hanson, Patrick Honohan, Larry Promisel for helpful comments on earlier drafts of this paper.
} 


\section{Introduction.}

Convergence of financial regulation across jurisdictions has been considered, at times a precondition of market integration, at times a consequence, but always a key feature of financial integration. In the last decades the relationship between financial integration and regulatory harmonization, in its various guises, has changed as a result of the accelerating pace of financial globalization. Not only have capital flows increased enormously, but also the provision of financial services across different jurisdictions has grown as a result of the expansion of financial intermediaries internationally and of the direct supply of financial services to foreign entities, as in the case of foreign listings. It can be argued that the increased provision of financial services and products across national boundaries has already exercised a disciplining effect through stiffer competition. Still, the integration of financial products and services and that of financial regulatory frameworks represent two different aspects of the same process, the globalization of finance. They move together but often at different speeds.

Although market forces can promote regulatory harmonization, regulatory developments should not be left to market forces alone. Market forces and self-regulatory agencies share well known problems. Coordination failures associated with market-led initiatives can generate negative systemic externalities, attracting capital toward less regulated systems and institutions or generating forms of competition in laxity that may undermine financial stability. In addition, the cost of financial regulation and supervision may be too high for small countries a potentially critical issue in the development of sound standards in a world where the number of independent jurisdictions has almost trebled since World War II. Overall, welfare considerations related to the presence of systemic externalities and to the high cost of public goods suggest that regulatory harmonization should not be left to market forces alone.

From the perspectives of the national policymaker and the analyst of international financial relations the relevant question then becomes how financial regulatory harmonization should be pursued. How should a specific country overcome the tension between its own national political dimension and its global economic interests? 
This paper will explore in greater detail the regulatory dynamic that has emerged as a result of a period of unprecedented internal and external financial liberalization, and of unprecedented banking and financial crises around the world. We shall argue that the globalization of finance has altered the relationship between trade and financial integration - the when of the process - and this has affected the methods and procedures of integration - the how of the process - defining new paths of regulatory harmonization and convergence.

We start by comparing the ongoing dynamic of financial integration with that of the post-World War II period to assess whether we are moving on familiar ground or into uncharted territories and what use can we make of past experience. Then, by means of a deliberately stylized characterization of the ongoing process of regulatory harmonization we shall try to focus on the main strengths and weaknesses of the emerging international trend in the globalization of finance represented by the worldwide dissemination of codes and standards of best practice. More specifically, we shall characterize the emerging process as a particular blend of the two traditional forces behind regulatory harmonization - official and market forces - and will suggest that this feature explains both the striking popularity currently enjoyed by the standard and codes approach and the nature of its limits.

From this perspective we shall discuss the role and limits of the ongoing worldwide dissemination of standards and codes; the role and responsibilities of the International Financial Institutions (International Monetary Fund, World Bank, and the regional development banks, IFIs) in guiding and monitoring the process of regulatory convergence; and, finally, the nature of regulatory convergence itself. The paper is structured as follows. Section 2 will compare the ongoing regulatory harmonization process with the experience of past episodes of financial integration. Sections 3 and 4 will explore the role of government led and of market led initiatives in the transition from segmented to integrated capital markets and will draw some lessons of general validity. Section 5 will analyze the ongoing process of international diffusion of standards and codes, the reasons behind their widespread popularity and their limits. Section 6 will draw some tentative conclusions. 


\section{Financial integration: how and when.}

Countries facing the many policy questions raised by the integration of financial markets are likely to look at past experiences for guidance. It is therefore natural to provide an initial characterization of the present process in terms of similarities or differences with past phenomena of financial integration and regulatory harmonization. Looking back at the past fifty years the question then becomes: how much and where has the process changed in the last two decades with respect to the previous ones?

For this purpose we shall consider three constants in the regulatory process: its interaction with other components of the legal and regulatory framework; the nature of the rule-setting institution; the level of cogency of the rules. Looking at the dynamic of the regulatory process, we shall consider what sequence of regulatory events (trade versus financial integration), of the rule-setting institutions (political versus technical authorities) and of rules (binding versus indicative) best characterize the present evolution of financial regulation.

Under the first point, it is relatively straightforward to observe that, if the sequence trade ? finance has characterized past episodes of economic integration, it is losing relevance today. In the 1960 s and 1970s economic integration between countries followed a relatively standard pattern with trade liberalization coming first as a necessary condition for the prospective integration of productive sectors ${ }^{1}$. Financial integration was the result of increased provision of foreign financial services associated with the trade of goods rather than an independent phenomenon (Aliber, 1984). ${ }^{2}$ Napoleon's sentence "l'intendence suivra"” could be paraphrased with "la finance suivra", to characterize the ancillary notion that was traditionally attached to the provision of financial services across jurisdictions. This view reflected the general perception that a successful commercial integration was the first and most relevant policy objective while financial

\footnotetext{
${ }^{1}$ Rousseau and Sylla (2001) find that trade integration in the postwar period was not affected by financial integration; Lane and MilesiFerretti (2000) find that still in the 1990s financial openness benefited from the level of trade integration.

2 Countries that deliberately liberalized capital movements more than or before trade are concentrated in Latin America. An IMF report (2002) finds that the Region has the highest concentration of countries closed to trade and financially open and the largest vulnerability to episodes of financial instability.
} 
integration played at best a supporting role ${ }^{3}$. The European integration process followed this pattern - from a restricted number of goods markets (steel and coal) to the entirety of goods and then financial markets. However, the current globalization of international finance markets is depriving the trade ? finance sequence of its relevance. Financial integration takes place independently from the level of economic integration and, despite the fact that evidence still support the notion that trade liberalization is "essential to reap the full benefits of capital account liberalization" (IMF, 2002), the traditional trade ? finance sequence appears to have been increasingly substituted de facto by a new finance ? trade sequence.

An aspect of this new course of events is the observed diffusion and adoption of codes and standards of good practice across economies at different levels of development, of structure, of openness as a tool to limit the destabilizing effects of international capital movements. The emphasis on financial integration from this perspective does not signal a shift of concern from the real to the financial sector of the economy or from real to financial integration. It simply considers finance instrumental to the process of economic integration instead of residual, and this change of perspective has led to an inversion of the timing of desirable regulatory harmonization. ${ }^{4}$

The second feature of interest concerns the difference in the involvement of rulesetting institutions: government and non-governmental institutions, where the notion of non government institutions is extended to include technical bodies such as supervisory authorities. Traditionally, governments have set the rules for a more intense economic cooperation among countries, both at a bilateral and at a multilateral level, through treaties, memoranda of understanding or other official forms of agreements. Official agreements usually paved the road for closer interactions between private sector actors and institutions. From the 1970's onward, instead, "non governmental " sector initiatives have often taken the lead in setting the pace for and even forcing government interventions in the financial area. With increasing frequency initiatives stemming from

\footnotetext{
3 More generally financial integration was an element of concern, given the additional constraints imposed by greater capital mobility on the pursuit of objectives of monetary policy different from those of balance of payments ${ }^{3}$ (Eichengreen, 1998).

4 The inversion of the sequence trade-finance has not been limited to financial regulation. Coffee (2001) reports the case of young Israeli firms that after accessing the US markets for funding purposes eventually decided to move the whole productive activity to the US. In this very specific case production itself has followed finance.
} 
the private sector and technical and professional bodies have tilled the ground to be sown by political authorities. The best known and probably one of the first of these non governmental technical institutions is the Basel Committee of Banking Supervisions, created in 1975, after the Herstatt crisis, with the purpose of strengthening and coordinating the supervision of internationally active banks.

A third feature of economic integration relates to the regulatory tools, i.e. to the legal and regulatory instruments used to promote integration. Earlier, government involvement was primarily limited to treaties, whether bilateral or multilateral. The extreme length of international treaties negotiations and approval compared with the speed of financial innovations in the marketplace has made these traditional tool of international diplomacy ineffective in the financial domain. Now non-governmental bodies, stemming both from the private and official sectors, have taken the lead in defining new rules of behavior. Sometimes the form of the new rules is that of codes of conduct or of benchmarks against which to compare and assess individual behavior. Governments have also used this approach, for example, compiling lists of non-compliant tax havens or off-shore financial centers. These rules are quite different from the traditional treaties in that they are intended to shape common behaviors without necessarily affecting the legal framework, a feature that we shall explore more in depth in the following sections. ${ }^{5}$ The sequence of integration rules has changed from the traditional sequence treaties ? codes of conduct to codes of conduct? treaties.

No matter how we look at it, the dynamics of global financial integration and the inter-related process of regulatory harmonization have taken a considerably different shape from the not so distant past. The tremendous growth of capital movements, related to technological developments and to current and capital account liberalization, have made the "when" of financial integration less dependent on other aspects of economic integration than in the past. The change in the "when", in turn, has inevitably affected the "how", making replicas of past solutions of limited use and requiring a new pragmatic approach to regulatory harmonization, one that is based on a process of trial and error and in which the received wisdom is constantly tested against the new emerging reality. Few

\footnotetext{
${ }^{5}$ It must be noted that a parallel shift from multilateral (formal) to non institutional (informal) fora, such as the G7, G10, and G20, has characterized international economic cooperation since the mid-1980s (PadoaSchioppa and Saccomanni, 1999).
} 
features of past approaches to regulatory integration have survived this reality check. The next two sections will single out these features from past episodes of government and of market induced regulatory harmonization as a step toward the characterization of the emerging approach to regulatory harmonization: the standards and codes approach..

\section{Government Induced Regulatory Convergence.}

Capital controls largely insulated national economies for the period between World War 1 and the early 1980s reflecting the lack of interest in the process of financial integration and the ease of controlling capital flows, compared to today. In the few cases where integration among different financial systems was actively pursued it was largely the result of political decision. Recent historical experience shows that in three clearly defined sets of circumstances, government induced integration has been significant and there are lessons to be learnt.

Probably the most economically important case of the three is the "trade induced case". It refers to those countries where the presence of a tight network of trade relationships has induced governments to promote a stronger form of integration by partly waiving their national sovereignty in deference to a supranational regional authority. The typical example is given by Western European countries that, building on strong commercial ties, have successfully moved toward an economic and a monetary union. Similar objectives and ambitions have been pursued by governments elsewhere less successfully, by the Latin American countries of the Andean Pact and the MercoSur, for example.

The second set of circumstances can be labeled the "dominant neighbor" case, where a country's economy is significantly affected by the proximity of a large neighbor with a regional economic dominance. In this situation, national governments are induced to harmonize their financial laws and regulations with those of their large neighbor in order to improve the access of domestic firms and financial intermediaries to larger and more liquid foreign financial markets. Such a pattern characterizes the relationship between Western Hemisphere countries and the USA and between Eastern European and North African countries and the European Union. 
A third set of circumstances, more nuanced but still relevant, is represented by the common "colonial heritage" case. It is usual for the colonial heritage to persist in the legal and regulatory frameworks of former colonial powers but in some cases it also extends to the selection of monetary arrangements similar to those prevailing during the colonial period. This is the case of the West African Monetary Union (WAMU) and of the Central African Monetary Union (CAMU) among French speaking countries and of the East Caribbean Currency Union (ECCU) among English speaking countries. A significant feature of these monetary unions is that - contrary to the European Monetary Union - they have not always been preceded by full trade liberalization; tariffs may still apply to trading between countries sharing the same currency and monetary authority, which is an example of the inversion of the traditional sequencing.

While government induced integration has presented specific challenges in each of these three cases, the European experience is probably more instructive due to its complexity, the number and size of participating countries and the extent of financial integration. It is also the context in which, more clearly than in any other, the criteria for government induced regulatory harmonization across countries have been spelt out.

The convergence of macroeconomic and financial conditions throughout Europe, today, should not obscure the strong initial differences - structural and economic - that prevailed among the twelve EU countries. Different regulatory frameworks, different degrees of openness of capital markets, different roles of commercial banks (universal versus specialized), different corporate governance arrangements (bank-based versus market-based control) were the norm among Western European countries until the 1980s, and partly still are. To fully appreciate the extent of regulatory harmonization it is interesting to observe that all the four legal families made popular by the current debate on the interaction between law and financial systems (La Porta et al.,1998) were and are represented among EU member countries.

These deeply rooted structural differences showed no sign of diminishing between the 1950s and 1970s when an objective of full harmonization was pursued. Starting in the mid 1970s, a new strategy based on the principles of subsidiarity and minimum harmonization was undertaken. The subsidiarity principle implies that supranational authorities should limit their rule making activity only to those areas that cannot be covered by national jurisdictions. The minimum harmonization principle instead requires 
two ancillary principles to be operative: the mutual recognition of foreign regulatory systems (recognition of the validity of foreign regulation) and the principle of home country control (recognition of the validity of foreign supervisory authorities).

The longevity of the approach from a regulatory point of view is indicative of its effectiveness, also if the integration of financial markets may not have followed suit. The key feature of the new approach has been the substitution of the traditional top-down process - based on the compulsory compliance with a detailed list of centrally issued regulations - with a new process where only a minimum number of common rules had to be defined while further harmonization was left to market forces. Competition among regulations and regulatory systems was allowed to operate while the minimum set of rules acted to avoid a "competition in laxity". It must be emphasized that minimum harmonization has been successful where inclusive (i.e. all the participants in the harmonization process participate in the definition of the minimum standards). Harmonization of regulatory systems is not an easy process at the best of times and often proves illusory where distorted by asymmetries in size and influence (Greene et al,.1995; Scott, 2000).

Finally, a new set of issues has recently entered the European debate on regulatory harmonization, concerning the need for different standards for wholesale and retail markets. An approach focused uniquely on the definition of minimum regulatory standards for the three main actors of the marketplace - banks, insurance companies, securities intermediaries - has been judged inadequate unless tailored to the size of the transactions and of intermediaries involved (European Commission, 1999). With the inception of the Euro and the progressive despecialization of financial intermediation, it has become increasingly important to distinguish between the requirements applicable to large players - be they corporations, asset management companies or payment systems or to retail investors in the furtherance of consumer protection.

Summarizing, two lessons can be highlighted from the European experience that may be applicable to financial integration more broadly. First, the principle of minimum harmonization together with mutual recognition principles underlines the potential for leaving integration to market forces once national legal and regulatory frameworks share common minimum standards. Secondarily, in a financially integrated world, size matters 
both for regulated entities and for the regulators and the same set of rules may not be efficient and equitable for both large and small players.

\section{Market Induced Regulatory Convergence.}

All regulatory convergence must start with the market(s), but markets themselves are institutions that represent a shared set of rules, the very existence of which rests on some initial agreement or shared regulatory principles. There is therefore a more intimate relationship between private forces and the rulemaking process than is frequently perceived. Private contracts have almost invariably shaped the initial development of most financial institutions up to the point where the emergence of externalities of some sort has required the intervention of the public regulator. Notwithstanding the emphasis that the analysis of regulatory convergence in financial, and in particular, capital markets, has put on formal regulation, the role of private legal rules as a factor of regulatory convergence remains of primary relevance.

The relationship between private contracts and formal regulation should not be viewed as static but as a dynamic continuum. (Jordan and Lubrano, 2002). The same "rule" can take multiple forms and over time travel back and forth as a swinging pendulum between the two extremes of private legal rules (based on contract or convention) and formal legislation. For example, over time fairly standardized private legal solutions found in shareholder agreements or private company by-laws have taken the form of regulatory requirements embedded in commercial codes or securities regulation. Several contractual governance mechanisms developed in the context of private companies (tag along rights for minority shareholders in the event of a change of control, for example), were adapted and crossed over to the realm of public corporations; their outlines, for example, can be seen in the 1964 Williams Act in the United States, the source of US tender offer rules. In turn, legal restrictions have determined the appearance of new variants of the original contracts.

Overall market induced regulatory harmonization, as we see it, has operated in two ways: 1) through the dissemination of best practices by opening markets to new players and new products consistent with these practices and 2) through the creation of new contractual standards. It has been argued that opening domestic markets to the presence 
of foreign qualified institutions has favored the interaction of supervisory agencies disseminating good quality supervisory regulation and practices (Levine, 1996). Analogously, the attractiveness of listing on foreign stock markets has resulted in good quality accounting standards being disseminated across different jurisdictions, without the imposition of formal regulatory requirements.

Moreover, market-led initiatives can help to define new contractual standards. New contractual arrangements, motivated by regulatory arbitrage, have not always survived the removal of the arbitrage opportunity but in a few cases new market standards have brilliantly outlived their originating cause, as in the case of the standardized practices underpinning the Euromarket and of the placement standards for the ADRs.

The Euromarket has sometimes been characterized, erroneously, as an "unregulated" market. It is a highly specialized wholesale market originally tailored to US issuers raising debt financing from European investors, that over time has attracted issuers of other nationalities and has diversified into different instruments such as derivatives and equities. Taking advantage of the difference in the fiscal and legal characterization of the transactions (as between the US and Europe) market practitioners have skillfully flown below the radar screen of formal national regulation. US regulators looked at the nature of the transaction; if it was centered in Europe, they let it go. European regulators looked at the nationality of the issuer; non-European issuers did not trigger a regulatory response. The Euromarket flourished in the interstices.

The Euromarket, like the derivatives markets it fostered, has operated for decades on the basis of standard contractual forms and industry association rules and practices without indications of egregious market abuses. When the threat of formal regulatory intervention loomed in the early 1990s in the form of the European Commission's Investment Services Directive, the industry association and practitioners quickly closed ranks, beefed up their rule book and bolstered their industry oversight ${ }^{6}$. The Euromarket has demonstrated all the usual virtues of private legal rules, the virtues of contract: responsiveness to market conditions and participants, flexibility, consensualism - virtues that make private legal rules especially suited to regional or supra-national specialized

\footnotetext{
${ }^{6}$ A second threat has loomed with the proposed European Prospectus Directive. In July 2001, the UK Law Society warned that the proposed directive risked killing the only truly pan-European securities market and accommodations were subsequently made to the proposals.
} 
markets. Of course, this approach is not suitable for every market nor for every aspect of a market; but is highly effective given the right conditions.

American Depositors Receipts (ADRs), represent another interesting example of standardized practices that have led to the creation of a cross-border market. ADRs have provided a means for US investors to diversify internationally from the comfort of home while providing some US banks with a tidy fortune in fees as intermediaries and custodians. The popularity of ADR during the 1990s soared. In the period 1990-1999 the depository receipts programs grew from 352 to 1,800 and the countries involved from 24 to 78 (Claessens et al. 2000). The ADR market, like the Euromarket, began as a private market based on regulatory arbitrage. The "receipts", carefully named to avoid characterization as a "security", were issued in the United States by a number of US banks, backed by the "deposit" of non-US issuer securities. As a result of a series of negotiations between the industry and the Securities and Exchange Commission (SEC), ADR were the object of a compromise solution in terms of regulation and disclosure requirements, which exceptionally spared US bank liabilities under US securities law ${ }^{7}$.

The critical lesson of previous examples is that markets have the capacity, not only of spreading existing standards across jurisdictions but also, and more importantly, to develop contractual and regulatory standards through arbitrage and competition. Financial innovations, frequently devised to circumvent regulatory inconveniences such as prospectuses or taxation, as in the case of Euroloans and ADRs, often address more general financial needs and achieve significant and stable development. Market induced regulatory convergence can therefore be characterized as the process that operates through the competitive selection and refinement of contractual standards.

Market forces alone are not always able to successfully enforce the standards that they have helped to set, however. Market discipline is exerted through the pricing mechanism and is as good as the quality of the available information or of the incentives to properly price risk. Where these conditions are not attained, the traditional mechanisms of public censure and reputation costs - the traditional forms of sanctions levied in cases of market abuses -may lose their effectiveness. Nevertheless, for markets

7 There are three "tiers" of ADR programs recognized, with graduated disclosure requirements ranging from an exemption from formal SED filings to full US prospectus registration (SEC Release No. 336894, May23, 1991) 
characterized by a limited number of large players, reputational costs have provided a quite effective disciplining instrument as confirmed by the lack of episodes of market abuse over extended periods of time.

\section{The new consensus on minimum standards and codes.}

As we have seen, government induced regulatory convergence has led to different forms and models of regulatory harmonization. In a few but significant areas of the world it has made possible the establishment of monetary unions, as in the case of Western European, Eastern Caribbean and African Franc Zone countries. In other regions, the gravitational pull of one or more large and successful countries acted as acatalyst, favoring a process of regulatory alignment. The experiences in these regions have shown that the difficulties of a "top-down" harmonization - whereby a political authority imposes common rules across jurisdictions - can be reduced by invoking instead principles of the minimum harmonization. It is difficult to overestimate the importance of the minimum harmonization principle for the process of global financial integration.

Market mechanisms also have had some success in developing and enforcing financial standards through reputational discipline. Reputational discipline has been important where market determined standards prevail and where a limited number of large institutions dominate the marketplace. In these cases standardized market practices have proved to be effective for extended stretches of time, even in the absence of public (administrative or penal) sanctions.

These principles - minimum harmonization and mutual recognition on one side and reputationally induced discipline on the other - represent probably the most effective lessons that past episodes of financial integration carry over to a world of integrated capital markets. Both of them play a major role in the regulatory response to the globalization of capital that is currently represented by the standards and codes approach. That approach, in fact, has taken the form of a minimum set of rules embedded in codes of best practice, adopted by national policymakers on a voluntary basis in order to improve the strength and reputation of their financial systems in the international marketplace. Reputationally induced discipline has been strengthened by "official" incentives such as the "name and shame" practice associated with the Financial Action 
Task Force (FATF) lists of non-cooperating jurisdictions or with the OECD list of offshore financial centers responsible of harmful tax competition. ${ }^{8}$

The combination of these two components has favored the unquestionable popularity of the approach for at least three reasons . First its hybrid nature, that combines both elements of market and regulatory discipline appeals to a potentially very large constituency within each national financial system including market regulators and market practitioners. Second, its generality has favored a large receptiveness on the part of countries with different history, level of development and geographical location. This has proved to be tremendously important in a period characterized probably by the largest process of regulatory and legal reforms in history, both in terms of the number of countries involved and of the extension and pervasiveness of the reforms considered. Finally, the relative conceptual simplicity of minimum harmonization approaches may have conveyed the fallacious impression that the standards and codes approach could represent an easy solution to complex questions posed by the financial regulatory reforms. A similar order of considerations may have induced to consider compliance with standards and codes instrumentally, as a signaling device.

The large popularity of an approach by which national adherence to a set of international standards and codes has been pursued on a voluntary basis raises several questions: Are we observing a wholly new pattern? What levels of effectiveness can be expected from this regulatory approach? And what are the potential shortcomings?

The process is by no means a new one. The presence of norms of behavior that fall short of having the binding force of legislation has been commonly observed, especially in Commonwealth countries, at a national level ${ }^{9}$; such conventions or standards have generally been referred to as "soft law" due to the lack of a codified procedure for their definition and of means of legal enforcement (law suits) (Giovanoli, 2001). The ongoing process of dissemination of international standards and codes represents very much a

\footnotetext{
${ }^{8}$ Additional "official" incentives play a role in the standards and codes approach and are related to the surveillance activity performed by the IFIs. They do not appear to be as central to the characterization of the approach as the reputation factor.

9 "English common law system demonstrates a surprising aversion to law as legislation, to ex-ante public legal rules. Large and complex swathes of English law are found in no written legislated form. Trust law, from which is derived the concept of fiduciary duties is a prime example; its fundamental principles remain judge-made, their source being ex-post public legal rules. England is a country with no written constitution for example." (Jordan and Lubrano, 2002).
} 
transposition at the international level of the notion of "soft law". As in the case of national "soft law", the adoption of codes of best practices is purely voluntary and is the expression of a social consensus that, at the international level, has taken the form of nontreaty international pronouncements such as "codes of conduct, guidelines, recommendations, declarations, and resolutions of international organizations “ (Kim, 2001). Although "soft laws" share common advantages over formal law both at the domestic and at the international level, such as greater flexibility and timeliness, a few important differences still persist between their national or international version.

The first difference between the role of soft laws in the international and national financial context is that international "soft laws" represent a "substitute" and not a complement to "hard law" provisions, due to the substantial absence of international "hard" laws (Giovanoli, 2001). As a consequence international "soft laws" are deprived at the international level of the opportunity, available for national "soft law" provisions, to find over time formal expression in national "hard laws" and regulations. What we observe, instead, is that in finance soft law provisions tend to percolate down from the international to the national level, often transforming themselves into national hard laws and formal regulations rather than international treaties. This differs from practices in the international trade domain where the traditional "hard law" strategy is still followed (for example, the WTO). We shall refer to the interaction between international soft laws and domestic hard law as to the complementarity issue

A second difference is represented by the considerable proliferation of international standards and codes. One possible explanation of this phenomenon is the fact that standards and codes are a substitute for legal provisions at the international level: they fill the void left by the absence of international laws. As a result, the system of international codes and standards has reached a complexity that is a source of concern. An effort of coordination among different codes is required to avoid potential inconsistencies or simply different scope of coverage across standards. Lack of coordination, as we know, is one of the main shortcomings of "market led" developments and if not adequately dealt with may ultimately reduce the effectiveness of a "soft law" approach. We shall refer to this problem as to the coordination issue.

A third issue that is common to soft law provisions both at the national and at the international level is related to the "inclusiveness" of the process. Non-governmental 
bodies (as defined above) are ill suited to address and regulate the consequences of their own actions when they fall outside their constituency. In fact soft laws are similar to club-like arrangement and therefore not well suited to effectively address the impact of club members' actions on external constituencies (externalities). The question then becomes what weight should be given to non-club members in the decision making process? Or alternatively, how can the "soft law" approach become a more inclusive process? The issue is one of "legitimacy" (Giovanoli, 2001) and we shall refer to it as to the fair representation issue.

A more in depth discussion of the previous three points will help to focus on the challenges currently faced by the standards and codes approach and on some "gray" areas where further research is needed to revise and refine the current course of action.

\section{The complementarity issue}

The process of transformation of consensus views into national laws (the complementarity between "soft" and "hard" law) is particularly complex at the international level. Consistency of interpretation of the standards and codes across jurisdictions with different cultural and legal backgrounds cannot be taken for granted; this has been the main difficulty with the application of the subsidiarity principle in the European Union. In addition, compliance with different standards and codes is purely voluntary. These factors have led to attributing responsibilities in the dissemination and monitoring of codes and standards to institutions which represent a large number of national jurisdictions and with a mandate to promote conditions for economic stability and development internationally such as the IMF, the World Bank and other regional development banks (the IFIs). ${ }^{10}$

Observers of the process claim that the dissemination activity performed, by and large, although not exclusively, by the IFIs has triggered substantial national legislative and regulatory activity (Kim, 2001). An illustration of the Korean case may provide an example of the complementarity of international soft laws and national hard laws, as well as of some of its potential criticisms. Following the 1997 crisis, the Korean government

${ }^{10}$ See the IMF and World Bank, 2001 
revised its financial sector legislation providing legal force to several international best practices. The Basel Capital requirements for commercial banks were adopted by law and regulation; mutual funds - until then not present in the Korean market - were introduced; corporate governance criteria were revised and regulated by law. Among the laws that were revised we can refer to the new Korean Banking Act, the Law on Merchant Banking Companies amended to adapt to the Basel capital requirements, the Korean Stock Exchange Act revised to ensure compliance with sound asset management procedures and the protection of small shareholders and the Securities Investment Company Acts which led to the introduction of mutual funds in the Korean marketplace (Kim, 2001).

Critics of the process have questioned the timing and sequencing of the reforms more than the relevance of the process itself. In the Korean case existing concerns have been summarized by the dilemma "restructuring out or growing out" (Park, 2001). According to this view the emphasis on "structural reforms may have been excessive" and without a significant impact on the growth potential, given the speed of the recovery (Kim, 2001).

The presence of criticisms has not prevented the dissemination of international standards and their incorporation in national laws to become a widespread phenomenon and one that has not been limited to crisis countries - where IFIs conditionality may have played a larger role - but that has widely involved non-crisis countries as well. The assessment of compliance with the major codes and standards performed by the IMF and the World Bank as part of the Financial Sector Assessment Program (FSAP) and the Report on Observance of Standards and Codes (ROSC) is an indication of a truly worldwide interest in aligning national legal and regulatory frameworks with international best practices.

The attractiveness of the "soft law" approach is confirmed also by the number of countries that have voluntarily participated in the FSAP program. As of June 2002 - two years and a half after the launch of the program - about sixty countries had already participated in the program (equally split into high and upper-middle income countries and low and lower-middle income countries). The popularity of the initiative is even more remarkable if we consider that a) reforms of legal and regulatory systems have been 
traditionally a domain of exclusive national competence ${ }^{11}$; and b) most "international standards" have been drafted in the past five years and represent very much a first generation efforts that has yet to undergo revisions and refinements as experience accumulates with their application.

It remains to be verified whether the popularity of the approach may hide some elements of weakness. The question of implementation is of course important and an issue given the differences in culture and legal history. Secondarily, some national governments might even perceive compliance with international codes as a signaling reputational device and this may actually mitigate pressures to fully enforce the to changes of the "law in the books". Poor enforcement and its potential causes could well be one of the central issues to be addressed by the next generation of standards and codes. From this perspective two elements may prove to be of particular relevance: 1) the degree of effectiveness of legal transplants in countries with different legal infrastructure and different level of development and 2) the role that size of the financial sector plays in the design of an effective regulatory infrastructure.

The popularity of various international standards and codes has resulted in the proliferation of "transplanted" legal concepts into national legal systems that has attracted the attention of legal commentators (for example, Pistor, 2000b, Jordan and Lubrano, 2002). The debate on the effectiveness of legal transplants suggests that "international" standards, or part of them - insofar as they represent transformations of national practices, institutions and legal concepts prevailing in developed countries - may not travel well to emerging or transition economies (Pistor, 2000a). Not all of these transplants thrive; some are patently ineffective domestically. They may be incompatible with the underlying domestic legal system (eg., common law fiduciary duties in Roman law legal systems), be introduced by "special" legislation that is inconsistent with and

\footnotetext{
${ }^{11}$ The confidentiality of the assessment of compliance conducted during the FSAP missions has favored full cooperation between national governments and the IFIs giving to the assessments the nature of an "external audit" for use by the national authorities to assess institutional weaknesses and define policy priorities. However, national governments are encouraged to make public the main findings of the FSAP that are embodied in the related documents prepared for the Boards of the IMF and the World Bank.
} 
trumped by a civil or commercial codes, or implemented in a form that is not recognized by the particular domestic legal system ${ }^{12}$.

The most common difficulty in the area of financial regulation is the absence of a broad concept of "fiduciary duty" in Roman law legal systems. The fiduciary duty is indigenous to the Anglo-American legal system and supports a wide range of institutions and regulatory structures; it is the "hidden assumption" upon which much of capital markets regulation and corporate governance rests in the common law world. As a legal concept, the fiduciary duty is very difficult to replicate in Roman law systems, for a variety of reasons. As Roman law legal systems are the most prevalent in the world, ranging from Europe across North, West and South Africa, throughout Latin America and many parts of Asia, the adoption of the institutions and regulatory structures proposed by international standards rooted in the Anglo-American legal tradition, without a compensatory mechanism to mimic fiduciary duties, may be creating a widespread regulatory hazard. The widespread looting of newly privatized entities in Central and Eastern Europe (and subsequent collapse of small country capital markets like those of Slovakia) was in part attributable to this phenomenon. A more recent example would be the difficulties encountered in Korea with investment trust company structures.

It is also questionable whether standards developed in and designed to fit large and developed economies fit equally well small, emerging countries which account for the majority of jurisdictions around the world. Even independent from the level of development, the size of an economy is by itself an important determinant of the desirable structure and size of its financial and regulatory system. The fixed costs in setting up a regulatory structure, a market, a bank, are such that not many countries around the world can be expected to have all financial intermediation services produced domestically and conversely to have all the regulatory structures currently considered by the standards and codes currently in circulation.

For example, in many countries the classical tri-partition among banking, insurance and securities markets may not be conducive to a proper assessment of strength and

\footnotetext{
12 The reliance of Commonwealth countries on judge-made (ex-post) legal rules differently from the reliance of non-Commonwealth world on written (ex-ante) laws has often facilitated the implementation of voluntary codes of conduct in the first group of countries while has created problems of legal compatibility of voluntary standards in the second (Jordan and Lubrano, 2002).
} 
weaknesses of a financial system: it is too elaborate for small economies and too blunt for larger ones. Drawing again from the experience of the European Union, where the European Commission (1998) presented a Financial Services Action Plan (ironically another "FSAP") that was focused on the distinction between wholesale and retail markets, we may consider alternative schemes more attentive to the role that size plays in the production of financial and supervisory services. It may be more useful, for example, for countries with very small, illiquid stock markets ${ }^{13}$, to assess the conditions for establishing regional markets or for firms to access liquid foreign markets rather than to assess national compliance with IOSCO standards that reflect the experience of regulators with markets of average size and liquidity. One of the weaknesses of the standards and codes approach and of its operational legs (the FSAP and the ROSC programs) is to consider small emerging economies as Lilliputian replicas of large industrialized ones. In keeping with literary analogies, a more appropriate perspective might be that of Saint Exupery's Petit Prince whose major concern was the effect of trees and animals imported from Earth on his tiny planet. He should have added financial institutions.

\section{The coordination issue.}

We have suggested that the proliferation of international standards and codes may exemplify the lack of coordination that often precludes "first best" approaches to market regulation. The establishment of the Financial Stability Forum (FSF) in 1999, at the recommendation of a G-7 working group (Tietmeyer Report), was specifically directed to prevent such an outcome. The FSF was established, more generally, to assess vulnerabilities of the international financial system and to enhance the coordination among the many different authorities responsible for financial stability (bank, insurance, securities markets).

One of the first initiatives of the FSF was that of evaluating and ranking in a Compendium the different best practice codes proposed by different industry or regulatory bodies, indicating desirable priority of implementation. As of February 2000

13 Only 16 of the over 150 stock exchanges existing worldwide (Coffee, 2001) have an annual equity trading volume that exceeds 75 per cent of the equity market capitalization, as reported by Thomas and Shah in this volume. 
the FSF had identified 43 different codes with 23 more under consideration for inclusion. Of this list, twelve codes were defined as higher priority, of which five (the Basel Core Principles on Banking Supervision, the IOSCO Principles, the IAIS Principles, the CPSS Principles and the IMF Code of Transparencies in Monetary and Financial Policies Principles) are typically assessed by the IMF and the World Bank in the FSAP program.

A serious difficulty that dogs efforts of coordination of standards and codes is the relative absence of empirical evidence demonstrating a relationship between compliance with standards and financial stability. The initial evidence that linked indicators of legal and regulatory structure to the stability of banking and financial systems is based on very aggregate indicators of structure (Demirguc Kunt and Detragiache, 1998; Rossi, 1999). Only recently new empirical work has started to test the nature of relationship of specific and more detailed specification of regulatory structures with financial development and stability (Barth et al., 2002). But generally, the empirical evidence that links indicators of efficiency and stability to the legal and regulatory framework (see Schleifer and Wolfenzon (2000) for the effects on the cost of capital) has been based on indicators that have only an indirect relationship with the degree of compliance with international standards and codes.

The only available empirical evidence of international codes effectiveness refers to the Basel Core Principles (BCP) and shows the existence of a very weak and indirect link between the degree of compliance with BCPs and financial instability (Sundarajan et al, $2001)^{14}$. Compliance of bank supervision with the Basel Core Principles (BCP) may therefore be read as an indicator of the degree of "resilience" of a system to financial crisis rather than of its vulnerability to financial crises (Chen and Majnoni, 2002). Dissemination of international standards and codes may therefore represent a strategy directed at promoting financial services efficiency at large, by means of an improved quality of supervisory infrastructures, more than a specific crisis prevention tool.

\footnotetext{
${ }^{14}$ The prevailing uncertainty on the effects of the international standards and codes is best expressed in the language of a recent empirical paper on the effectiveness of bank regulation (Barth et al., 2002), according to which "there is no evidence that best practices currently being advocated by international agencies are the best ones for promoting well-functioning banks. There also is no evidence that successful practices in the United States, for example, will succeed in countries with different institutional and politic al environments".
} 
A second coordination issue concerns the resolution of divergences that are holding back the definition of an international consensus on relevant issues such as that of international best practices in the domain of accounting procedures, an area where the lack of an agreement among large industrial countries (exemplified by the different positions of the International Accounting Standards Board (IASB) and the United States Financial Accounting Standards Board (FASB)) has been an impediment to the definition of an international consensus view. In general, the reconciliation of different views at the international level has proven to be harder for the standards and codes more heavily conditioned by the prevailing legal framework, such as those related to corporate governance, accounting rules and security markets.

Clearer empirical evidence of the impact of best practices on economic stability, on one side, and definition of a consensus on controversial areas, on the other, represent important priorities to strengthen the credibility of the approach. Progress on both grounds should help to address a list of unanswered questions. Are, for instance, all the five standards typically assessed by the FSAP program equally relevant from the perspective of economic growth or stability? Do they always represent a priority with respect to accounting or corporate governance standards? And, should there be a standard addressing the role of competition authorities in promoting access to financial services for different economic sectors (retail, SMEs, corporate)?

These are questions that the next generation of codes and standards should answer, not only to improve the internal consistency of the approach but also, and more importantly, to avoid arbitrariness in the selection of "key" standards which may weaken the consensus around the approach itself.

\section{The fair representation issue}

The "fair representation" issue is a general feature of "soft laws" but it may present particular characteristics at the international level. Soft laws, as an expression of conventions, not laws, often materialize in the form of "understandings" or guidelines. Soft laws represent the consensus within a certain social or professional group of individuals and therefore cannot be expected to fully address the issues and problems that 
fall outside the group. As an expression of the view and opinions of specific constituencies they do not regulate potential externalities.

The "fair representation issue" has two aspects. The first is best described through a quotation from Giovanoli (2001). "Fair representation of all parties is crucial for the acceptance of standards with no legally binding character. On the other hand, it must be recognized that rules are much easier to draft in relatively small and manageable groups, as broad groups, especially if they are not homogeneous, move slowly and may fail to achieve the necessary degree of consensus. Reconciling at the international level the conflicting requirements of legitimacy and effectiveness is akin to squaring the circle".

There is, though, a second fair representation issue that is not related to the country composition of major international groups but rather is inherent to the composition of standard setters groups. In fact, standards setters may inadequately consider the impact of their decisions outside the areas of concern to their profession. A typical example of this point is given by the frequently raised concern that bank regulators represented in the Basel Committee devote too little attention to the pro-cyclical effects of the new of banks' capital discipline (Borio, 2002). While the Basel Committee has devoted renewed attention to the problem, modifying some of the most pro-cyclical features of the new capital discipline, the issue of the different emphasis devoted to the questions of stability and liquidity by different constituencies (namely, financial supervisors and economic policy makers) remains a policy issue of general relevance.

Another example of issues that are likely to fall outside the domain and interest of professional standards setters is the definition of standards for financial crisis management and resolution (Giannini, 2001). Responding to the lack of guidelines in this area the World Bank, together with the IMF and others have recently begun the process of formulating principles for dealing with bank and corporate insolvencies at both the individual and at the systemic level.

More generally, a full integration of the work on standards and codes with systemic considerations requires a "macro-prudential" approach to financial regulation (IMF, 2000). The debate on the systemic implications of the dissemination of codes and standards, though, has focused more on the ability of financial systems to withstand macroeconomic shocks (IMF and World Bank, 2002) than on the macroeconomic effects 
of new regulatory standards. For example, while considerable attention - and rightfully so - has been devoted to evaluating financial intermediaries capital adequacy by mean of appropriate stress testing exercises, only a modest effort has been put so far into assessing the effects of new of new solvency ratios on the allocation of credit.

\section{Conclusions}

The formulation of a new discipline for an international financial system has proven to be harder than in the past. The process of financial globalization has shifted the balance of power from governments to markets and has made the traditional solution, resort to international treaties - less viable. Historic references are often lacking and new institutional solutions are being tested through a process of trial and error. The dissemination of international codes and standards supported by IFIs represents an innovative and constructive effort in coordinating national regulatory dynamics. It combines some of the key features of the most successful episodes of regulatory harmonization - minimum harmonization and reputationally induced discipline - and represents, with all its limitations, a structured approach to the problems raised by the globalization of capital markets.

The still ongoing adaptation of financial regulation in transition economies, the reforms of financial system in crisis countries and in countries exposed to different degrees of financial contagion has generated a worldwide wave of financial reforms that has probably no historical antecedent in terms of geographical coverage and of extension within each financial systems. In this unprecedented environment the standards and codes approach has come to play an important role in promoting regulatory harmonization and reducing the risk of instability related to weak regulations and to regulatory arbitrage.

The standards and codes approach has the ambition to offer regulatory benchmarks for individual countries embarking in the process of reforming their financial systems and for this reason faces the difficult trade-off of pursuing an objective of generality without disregarding the needs of countries of different size, different legal tradition, and different level of financial development. The simple transposition of rules across different institutional frameworks may often lead to unintended consequences as the implementation of privatization schemes in transition economies has shown over the last 
decade. The challenges implicit in the standards and codes approach have undergone only an initial set of tests and the process of revision, assisted by the experience gained in the first years of application, has just started.

For example, a refinement of standards and codes or of their assessments appears warranted - and is underway in some cases — to accommodate different legal traditions and to deal with the specific needs of financial systems of different size and complexity. For small developing countries, that represent the majority of independent jurisdictions, the costs of financial regulation may require different regulatory structures than those prevailing in larger conomies. A clearer definition of the role played by different standards in promoting economic growth and financial stability would also help to set priorities among different regulatory reforms and would improve the effectiveness of the standards and codes approach as a whole. Finally application of international standards and codes may benefit from a further development of the macro-prudential approach that considers not only the effects of systemic shocks over financial stability (stress tests) but also the effects of different regulatory strategies on macroeconomic stability.

The success of the approach, according to the characterization provided in this paper, will ultimately lie in the capacity to provide operational content to its basic underlying principles of minimum harmonization and reputational discipline and to address not only conditions for the access to international capital markets but also and more broadly conditions for access to finance whether provided locally or internationally. 


\section{References}

Aliber, Robert, (1984), "International Banking: a Survey", Journal of Money, Credit and Banking, pp. 661-695, November.

Barth, James, Gerard Caprio and Ross Levine, (2002) "Bank Regulation and Supervision: What Works Best?", World Bank, mimeo.

Basel Committee on Banking Supervision (1999), "Sound Practices for Loan Accounting and Disclosure", July, mimeo.

Bongini, Paola, (2002), "The Liberalization and Regulation of Financial Services: a Multilevel analysis of the Gats 2000, European Union and Euromed initiative", mimeo.

Borio, Claudio, (2002), "Towards a Macro-Prudentiaal Framework for Financial Supervision and Regulation", mimeo.

Buiter, Willem, H., (2000), "Optimal Currency Areas", Scottish Journal of Political Economy, pp. 213-250, Vol. 47, n.3, August.

Chen, Xin and Giovanni Majnoni, (2002), "What Are Basel Core Principles Meant to Signal: An Empirical Analysis", mimeo.

Claessens, Stjin, Simeon Djankov and Daniela Klingebiel, "Stock Market in Transition Economies", World Bank Financial Sector Discussion Paper No. 5, September.

Coffee, John Jr., “ The Coming Competition Among Securities Markets: What Strategies Will Dominate?", mimeo, September 2001.

Demirguc-Kunt, Asli and Enrica Detragiache, (1998), "The Determinants of Banking Crises in Developing and Developed Countries", International Monetary Fund Staff Papers, Vol. 45, No.1, pp.81-109.

Eichengreen, Barry, (1998), "Globalizing Capital: a History of the International Monetary System", Princeton, University Press, Princeton, New Jersey.

European Commission (1998), "Financial Services: Building a Framework for Action", COM (1998) 625.28.10.98.

Financial Stability Forum, (2001), "Final Report of the Follow-up Group on Incentives to Foster the Implementation of Standards, September, mimeo.

Giannini, Curzio, (2001), "Broad in Scope, Soft in Method. International Cooperation and the Quest for Financial Stability in Emerging Markets", mimeo.

Giovanoli, Mario, (2001), “A New Architecture for the Global Financial Market: Legal Aspects of International Financial Standard Setting", in [....]....

Greene, Edward F., Daniel A. Braverman, and Sebastian R. Sperber, (1995) "Hegemony or Deference: U.S. Disclosure Requirements in the International Capital Markets", Business Lawyer, pp. 413-445, vol. 50, n.2.

International Monetary Fund, (2002), World Economic Outlook: Trade and Finance, September. 
International Monetary Fund, (2001), "Macroprudential Analysis: Selected Aspects" mimeo, June.

International Monetary Fund and World Bank, (2001), Assessing the Implementation of Standards: A Review of Experience and Next Steps, IMF Website.

Jordan, Cally, and Lubrano, Mike, (2002), "How Effective are Capital Markets in Exerting Governance on Corporations?", Financial Sector Governance: The Roles of the Public and Private Sectors, Washington: Brookings Press.

Kim, Hwa-Jin, (2001), “Taking International Soft Law Seriously: Its Implications for Global Convergence in Corporate Governance", Journal of Korean Law, March.

La Porta, Rafael, Florencio Lopez-de-Silanes, Andrej Schleifer, and Robert Vishny, (1998) "Law and Finance", Journal of Political Economy 106, 1113-55.

Levine, Ross, (1996), “Foreign Banks, Financial Development, and Economic Growth", in Claude Barfield ed., International Financial Markets, Washington, D.C., AEI Press.

Masson, Paul, R., and Taylor, Mark,P., (1992), "Common Currency Areas and Currency Unions: and Analysis of the Issues”, CEPR Discussion Paper n. 644.

Park, Jung Chul, (2001), “The East Asian Dilemma: Restructuring out or Growing Out”, Essays in International Economics, n. 223, Princeton University, August.

Padoa Schioppa, Tommaso and Saccomanni Fabrizio, (1999), "Managing a Market-led Global Financial System” in P. B. Kenen Ed, Managing the World Economy Fifty Years after Bretton Woods.

Partnoy, Frank, "ISDA, NASD, CFMA, AND SDNY: the Four Horsement of Derivatives Regulation ?", Brookings-Wharton Papers on Financial Services, January 2002.

Pistor, Katharina, (2000) "Patterns of Legal Change: Shareholder and Creditor Rights in Transition Ecnomies", European Business Organization Law Review.

Pistor, Katharina, et al, " Economic Development, Legality and the Transplant Effect", The Davidson Institute Working Paper No. 410 (2000).

Rossi, Marco, (1999), "Financial Fragility and Economic Performance in Developing Economies: Do Capital Controls, Prudential Regulation and Supervision Matters?, IMF Working Papers, No. 66, May.

Rousseau, Peter aand Richard Sylla, (2001) «Financial Systems, Economic Growth and Globalization”, NBER Working Paper No. 8323.

Schleifer Andrei and Wolfenzon Daniele, (2000) "Investor Protection and Equity Markets", NBER Working Paper n.7941, October.

Scott, Hal. S. (2000), "Internationalization of Primary Public Securities Markets", Law and Contemporary Problems, pp. 71-104. vol. 63, n.3.

Sundarajan, V., David Marston, and Ritu Basu, (2001), "Financial System Standards and Financial Stability: the Case of the Basel Core Principles" IMF Working Papers, No. 62, May. 